\title{
Preserving the sterility of surgical dressings wrapped in paper and other materials
}

\author{
V. G. ALDER AND F. I. ALDER \\ From the Department of Pathology, Royal Infirmary, Bristol
}

SYNOPSIS Materials for wrapping surgical dressings were studied by a method which measured $\frac{\rho}{\circ}$ the recontamination rate in packs stored for periods of up to several weeks. Of the materials tested a thick crêpe paper was better than calico and balloon cloth fabrics. Dressings wrapped in paper $\vec{\nexists}$ were not significantly contaminated after storage in dusty places for periods of up to three weeks. $\vec{\sigma}$ For added protection during handling and for convenience in transport and storage, paper packs ${ }_{\circ}$ may be sterilized and kept in paper-lined cartons. The shelf life in good storage conditions would be many weeks at least.

When gloves, dressings, and other fabrics have been sterilized in an autoclave, their sterility must be maintained during subsequent transport and storage. To achieve this the sterilized goods must be enclosed in containers or wrapped in materials which are as nearly germ-proof as possible, consistent with penetrability by steam, convenience in handling, and reasonable economy. In this paper we report the results of bacteriological experiments designed to evaluate various wrapping materials and containers, and we make some observations on their use.

\section{METHODS AND MATERIALS}

Test swabs were used to detect bacteria which succeeded in penetrating the container or wrapper after sterilization. The swabs were the cut-off ends of throat swabs made with wooden sticks. Several test swabs were enclosed inside each package, and were always in contact with the wrapper or the wall of the container. After sterilizing in a high pre-vacuum autoclave the packs and the containers were allowed to stand unopened for lengths of time varying from one day to three months in surgical wards, corridors, and other parts of the hospital. The places chosen were draughty and dusty. There were abundant bacteria in the atmosphere as shown by colony counts on $3 \frac{1}{2}$ in. nutrient agar sattle plates incubated aerobically for three days at $37^{\circ} \mathrm{C}$., which gave results between 40 and 100 colonies per hour.

The exposed packages were sampled in the laboratory by opening them and removing the test swabs as aseptically as possible. The swabs were placed in tubes of nutrient broth and, sometimes, Brewer's thioglycollate broth, which were incubated at $37^{\circ} \mathrm{C}$. for seven days, inspected, and plated out on blood agar for aerobic and some for anaerobic culture. The operation of transferring swabs to the bottles of broth, although carried out as aseptically as possible with sterile forceps, inevitably carries some risk of contamination (Pulvertaft, 1937; $\overrightarrow{-}$ Savage, 1940). To measure the frequency of laboratory $\mathscr{\sigma}$ contamination, negative controls were always put.through. These consisted of tins containing test swabs $\square$ which were sterilized in hot air immediately before the dressing packs were due to be opened. In order to equalize the chances of contamination as far as possible, the transfer of control swabs to broth was sometimes done $\frac{0}{\Phi}$ before, sometimes after, and occasionally during, the $\varrho$ transfer of the test swabs.

Of 518 control swabs transferred to broth, 20 gave $\frac{0}{3}$ positive cultures, a blank contamination rate of $3.86 \%$. The bacteriological efficiency of any packing method was measured by the degree to which its contamination rate exceeded this 'blank' figure.

The containers tested were cylindrical dressing drums, rectangular metal caskets with filter inserts in the lid 3 . and base and a gasket seal between the lid and body of the casket (G.U. Sterilizers Ltd.), and Bripac cartons.

The fabric wrapping materials, which were also sometimes used as liners in the other containers, consisted of unbleached calico and balloon cloth. The properties of these fabrics, determined by the British Cotton Industry‥ Research Association, are shown in Table $\mathbf{I}$.

TABLE I

THE PROPERTIES OF UNBLEACHED CALICO AND BALLOONN CLOTH* $^{*}$

\begin{tabular}{|c|c|c|c|c|}
\hline Cot & $\begin{array}{l}\text { Unble } \\
\text { Calico }\end{array}$ & ched & $\begin{array}{l}\text { Balloo } \\
\text { Cloth }\end{array}$ & \\
\hline & $\overparen{\text { Warp }}$ & Weft & $\overparen{\text { Warp }}$ & Weft \\
\hline Veight per unit area (oz./yd. $\left.{ }^{2}\right)$ & & & 3 & \\
\hline Threads per inch & 61 & 63 & 97 & 133 \\
\hline $\begin{array}{l}\text { Thickness at } 1 \mathrm{lb} . / \mathrm{in}^{2},{ }^{1} / 1000 \mathrm{in} . \\
\left.\text { Air permeability (ml. } / \mathrm{cm} .{ }^{2} / \mathrm{sec} . / \mathrm{cm} .\right) \\
\text { Equivalent pore radius (microns) }\end{array}$ & & 0 & $\begin{array}{l}1 \\
4 \\
2\end{array}$ & $\begin{array}{l}0 \frac{1}{2} \\
1 \\
9\end{array}$ \\
\hline
\end{tabular}

* Kindly supplied by the British Cotton Industry Research Association 
The papers tested were (1) heavyweight crêpe paper of substance weight $28 \cdot 1$ with a high tear and stretch strength (Sterilwrap, Bowater Scott Corporation Ltd.) and (2) bleached Kraft paper of substance weight $22 \cdot 0$ (Messrs. E. S. and A. Robinson Ltd.).

\section{RESULTS}

Tests with unlined containers showed that only the metal caskets with filter inserts and a washer seal gave satisfactory results. Cardboard cartons (Bripac), although not satisfactory without linings, had a much lower contamination rate than unlined drums (Table II).

TABLE II

CONTAMINATION RATES OF LINED AND UNLINED CARTONS AND METAL CONTAINERS

\begin{tabular}{|c|c|c|c|}
\hline & \multicolumn{3}{|c|}{ Storage Period 12 to 17 Days } \\
\hline & $\begin{array}{l}\text { Total } \\
\text { Swabs }\end{array}$ & $\begin{array}{l}\text { Contaminated } \\
\text { Swabs }\end{array}$ & $\%$ \\
\hline $\begin{array}{l}\text { Round drums, unlined } \\
\text { Round drums with calico }\end{array}$ & 85 & 17 & 20.0 \\
\hline $\begin{array}{l}\text { liners } \\
\text { Metal caskets with washer }\end{array}$ & 91 & 3 & $3 \cdot 3$ \\
\hline $\begin{array}{l}\text { seal in lids } \\
\text { Cardboard cartons, unlined }\end{array}$ & 82 & 2 & $2 \cdot 5$ \\
\hline $\begin{array}{l}\text { (Bripac) } \\
\text { Cardboard cartons (Bripac) }\end{array}$ & 198 & 15 & $7 \cdot 6$ \\
\hline $\begin{array}{l}\text { with htted bleached Krat } \\
\text { paper liners }\end{array}$ & 139 & 6 & $4 \cdot 3$ \\
\hline
\end{tabular}

(Blank control 3.86\%)

Both of the lined containers (drums and cartons) were bacteriologically efficient, with contamination rates which did not differ significantly from the blank control (Table II).

Except for the muslin, the fabric and papers tested may be used in one or more layers for either dressing packs or as linings for rigid containers. It was therefore necessary to assess their efficiency as barriers against recontamination. The results are shown in Fig. 1, in which each point represents the

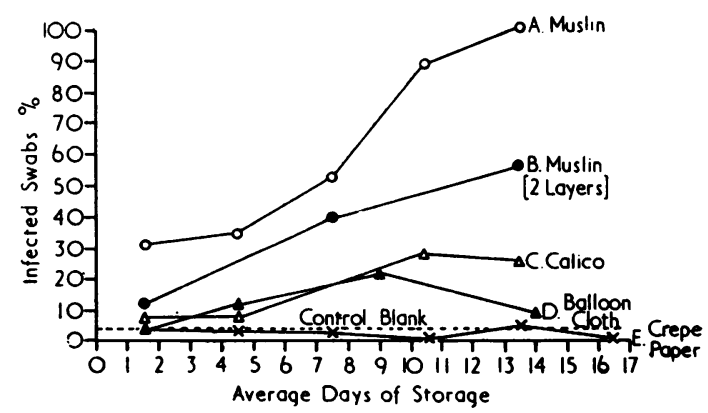

FIG. 1. The contamination rates for crêpe paper and fabrics. contamination rates of at least 24 test swabs and usually many more. (Bleached Kraft, not included in Fig. 1 gave results not significantly different from crêpe paper.)

As was to be expected, muslin was an inefficient barrier. Balloon cloth was better than calico but neither was as good as the paper, which even in a single layer, gave a contamination rate no higher than the blank figure. The few tests done with bleached Kraft paper showed that it was also more efficient than calico and balloon cloth. However, it was deficient in draping quality after it had been folded and autoclaved but was suitable for use as a liner or for making the paper bags in which small quantities of dressings are sometimes packed.

Although one layer of crêpe paper was bacteriologically efficient it should not be used routinely in a single layer because of the danger of puncturing or tearing during handling of the packages and damage from friction which may occur when many packages are handled together. Paper therefore should be used in double layers, and it will often be advantageous to enclose the packages so wrapped in rigid or semi-rigid containers, such as cardboard cartons, for added protection. The results of some packaging systems with paper and cardboard are shown in Table III.

\section{TABLE III}

CONTAMINATION RATES OF PAPER-WRAPPED PACKS WITH AND WITHOUT CARDBOARD CARTONS

\begin{tabular}{|c|c|c|c|}
\hline \multicolumn{4}{|c|}{ Storage Periods } \\
\hline & 13 Days & & o 21 Days \\
\hline $\begin{array}{l}\text { Total } \\
\text { Swabs }\end{array}$ & $\begin{array}{l}\text { Contaminated } \\
\text { Swabs }\end{array}$ & $\begin{array}{l}\text { Total } \\
\text { Swabs }\end{array}$ & $\begin{array}{l}\text { Contaminated } \\
\text { Swabs }\end{array}$ \\
\hline
\end{tabular}

\section{One layer of heavy-}

weight crêpe paper

The same in unlined cardboard cartons

The same in paperlined cardboard car-

tons

$\begin{array}{rrrr}62 & 1(1.6 \%) & 36 & 1(2.8 \%) \\ 172 & 5(2.9 \%) & 149 & 3(2.0 \%) \\ 118 & 0 & 229 & 7(3.0 \%)\end{array}$

(Blank control 3.86\%)

In these experiments, storage conditions were intentionally unsatisfactory. It may therefore be concluded that given good storage, the shelf life of packs wrapped in two layers of paper (and preferably enclosed in cartons for added protection) should be much longer than three weeks.

Although the paper and carton is highly efficient, it is rational to minimize the danger of recontamination by storing sterile packs under good conditions, i.e., in dry cupboards free from dust and draughts. The packs should not be stored for long periods in open wards where airborne pathogens may abound. 
The aerobic contaminating organisms in wards and corridors were investigated by tabulating the various species isolated from large numbers of packs of several kinds which had been exposed in the two situations (Table IV). Although most of the

\section{TABLE IV}

CLASSIFICATION OF AEROBIC CONTAMINANTS

\begin{tabular}{lcc} 
& $\begin{array}{c}\text { Packs Exposed } \\
\text { in Surgical Wards }\end{array}$ & $\begin{array}{l}\text { Packs Exposed } \\
\text { in Corridors }\end{array}$ \\
\hline Micrococci & 141 & 126 \\
Diphtheroids, B. subtilis & 63 & 110 \\
type, moulds, etc. & 7 & 0 \\
Staph. aureus & 5 & 9 \\
Coliforms & 2 & 0 \\
Proteus and Ps. pyocyanea & 4 & 0 \\
Streptococci & &
\end{tabular}

organisms were non-pathogenic, appreciable numbers of pathogens were present in the wards; there were fewer pathogens in the corridors.

The risks that dressings stored in various parts of the hospital might be contaminated by anaerobic pathogens were investigated by culturing test swabs from muslin-wrapped packs stored in wards, corridors, and theatre (Table V). The frequency with

\section{TABLE V}

DISTRIBUTION OF NAGLER-POSITIVE CLOSTRIDIA ON SWABS IN TEST PACKS EXPOSED FOR AN AVERAGE OF 7.5 DAYS

Total Swabs Exposed Positive Swabs

\begin{tabular}{llc}
\hline Three surgical wards & 73 & $35(48 \%)$ \\
Ward dressing room & 50 & $7(14 \%)$ \\
Corridors and theatre & 77 & $2(3 \%)$ \\
\hline Control swabs & 32 & 0
\end{tabular}

which $\mathrm{Cl}$. welchii was isolated in the wards was particularly striking. The principal sources were no doubt the large intestines of the patients and the main reservoir was probably their bedclothes. Several sweep plate cultures (Williams cited by Blowers and Wallace, 1955) show that $\mathrm{Cl}$. welchii was often present in used blankets.

\section{DISCUSSION}

The ideal wrapping material for dressings and other sterile goods should readily allow steam to penetrate and should maintain sterility for long periods afterwards. It should be cheap, robust enough to withstand handling, convenient to use, and popular with the members of the nursing staff. The paperwrapped packs inside paper-lined cardboard cartons possess these advantages. The rigidity and oblong shape of the cartons enables them to be easily handled in specially constructed carrying crates of perforated metal (Brig. J. D. Welch, personal

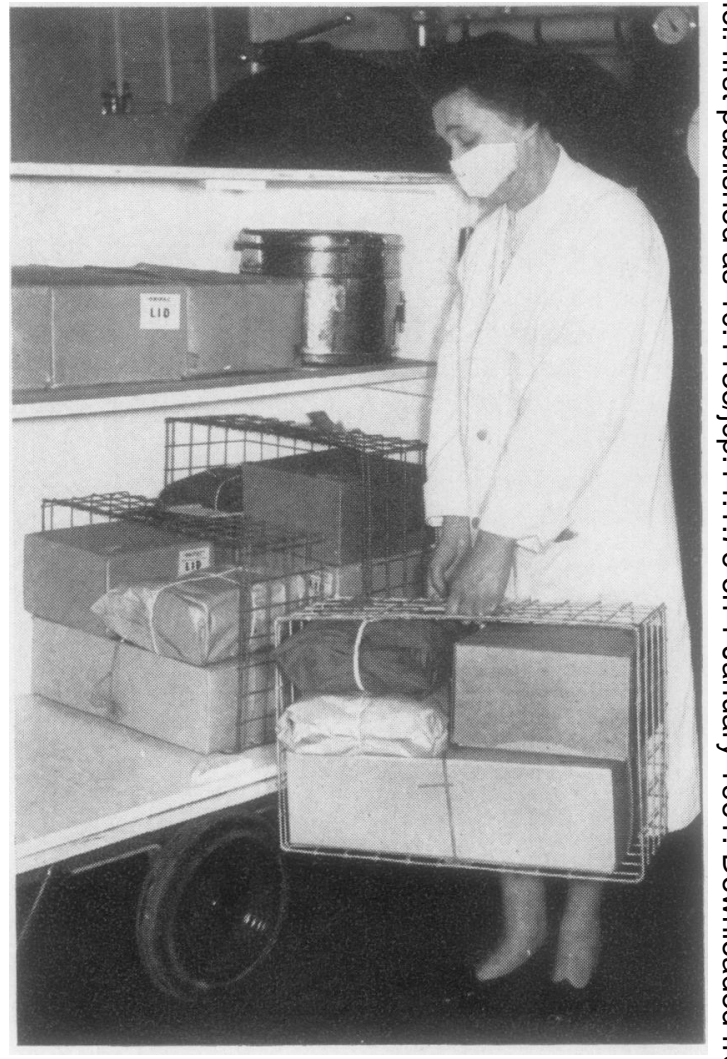

FIG. 2. Method of carrying cartons in crates and loading them into a truck opening from the side.

communication). With this system, one person can응 carry more dressings than can be carried by two people using drums (Fig. 2); this system is suitable 3 . for central sterile supply departments. The cartons are easy to stack on shelves. For carriage within the $\frac{3}{3}$ hospital a small covered truck may be used which should be reserved for the purpose of carrying sterile materials and preferably able to be opened for loading from the side.

Irrespective of the packaging method adopted, the steam for sterilization must be dry. This con- $N$ dition is particularly important when paper and cardboard are used. With dry steam, cartons remain ${ }_{\sigma}^{\omega}$ serviceable for more than two dozen autoclavings.

The long shelf life of packs wrapped in paper, with or without cardboard, should be of great valuee in hospitals served by central sterile supply depart-ments. The full shelf life of paper-wrapped packs has

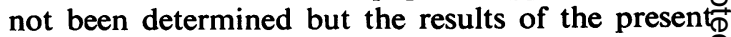
investigation show that detectable recontamination $\frac{?}{D}$ under good storage conditions would not occur for many weeks at least. 
Other kinds of paper may prove to be as efficient bacteriologically and even more convenient in use than the crêpe paper used in these investigations. But a good paper evidently provides a better wrapping material than the fabrics commonly used for this purpose.

We thank Dr. W. A. Gillespie for his help and advice,
Dr. E. M. Darmady and Brig. J. D. Welch for their encouragement, and the Trustees of the Nuffield Provincial Hospitals Trust for a grant towards the cost of this investigation.

\section{REFERENCES}

Blowers, R., and Wallace, K. R. (1955). Lancet, 1, 1250.

Pulvertaft, R. J. V. (1937). Brit. med. J., 1, 441.

Savage, R. M. (1940). Quart. J. Pharm. Pharmacol., 13, 237.

\section{Association of Clinical Pathological Broadsheets}

The following broadsheets (new series) are published by the Association of Clinical Pathologists. They may be obtained from Dr. R. B. H. Tierney, Pathological Laboratory, Boutport Street, Barnstaple, N. Devon, price 1s. each.

1 The Disc Technique for the Rapid Determination of Bacterial Sensitivity to Antibiotics. 1952. R. W. FAIRBROTHER.

2 Determination of Sensitivity of $M$. tuberculosis to Streptomycin. 1952. R. L. vollum.

3 The Detection of Barbiturates in Blood, Cerebrospinal Fluid, Urine, and Stomach Contents. 1953. L. C. NICKOLLS.

4 The Estimation of Carbon Monoxide in Blood. 1953. D. A. STANLEY.

5 The Identification of Reducing Substances in Urine by Partition Chromatography on Paper. 1953. G. B. MANNING.

6 The Paul-Bunnell Test. 1954. R. H. A. Swain.

7 The Papanicolaou Technique for the Detection of Malignant Cells in Sputum. 1955. F. HAMPSON.

8 Investigation of Haemorrhagic States, with Special Reference to Defects of Coagulation of the Blood. 1955. E. K. BLACKBURN.

9 Daily Fat Balance. 1956. A. C. FRAZER.

10 Mycological Techniques: (1) Collection of Specimens. 1956. R. W. RIDDELL.

11 Mycological Techniques: (2) Cultural Isolation. 1956. R. W. RIDDELL.

12 Techniques for Demonstrating L.E. Cells. 1956. J. V. DACIE and L. S. SACKER.

13 The Identification of Serotypes of Escherichia coli Associated with Infantile Gastro-enteritis. 1956. JOAN TAYLOR.
14 The Determination of Serum Iron and Serum Unsaturated Iron-binding Capacity. 1956. ARTHUR JORDAN.

15 The Estimation of Faecal 'Urobilinogen'. 1957. C. H. GRAY.

16 Preservation of Pathological Museum Specimens. 1957. L. W. PROGER.

17 Cultural Diagnosis of Whooping-cough. 1957. B. W. LACEY.

18 The Rose-Waaler Test. 1957. C. L. GREENBURY.

19 The Laboratory Diagnosis of Fibrinogen Deficiency. 1958. R. M. HARDISTY.

20 Investigation of Porphyrin/Porphyria. 1958. C. RIMINGTON.

21 Quantitative Determination of Porphobilinogen and Porphyrins in Urine and Faeces. 1958. c. RIMINGTON.

22 Investigation of Haemolytic Anaemia. 1959. J. G. SELWYN.

23 The Dried Disc Technique for Bacterial Sensitivity Tests. 1959. R. W. FAIRBROTHER and J. C. SHERRIS.

24 Safe Handling of Radioactive Tissues in the Laboratory and Post-mortem Room. 1959. R. C. CURRAN.

25 Titration of Antistreptolysin O. 1959. H. GOODER and R. E. O. WILLIAMS.

26 The Periodic Acid-Schiff Reaction. 1959. A. G. E. PEARSE.

27 The Laboratory Detection of Abnormal Haemoglobins. 1960 . H. LEHMANN. 